\title{
STRATEGI PENGEMBANGAN PETERNAKAN BABI DI DISTRIK HUBIKIAK KABUPATEN JAYAWIJAYA
}

\author{
Alber Tulak $^{1)}$, Khaerunnisa ${ }^{2)}$, Landius ${ }^{3)}$ \\ ${ }^{1), 2), 3)}$ Staf Pengajar Program Studi Agribisnis Sekolah Tinggi Ilmu Pertanian Petra Baliem Wamena
}

\begin{abstract}
ABSTRAK
Daerah kantong ternak babi di Indonesia salah satunya adalah Provinsi Papua yang dikenal memiliki kearifan lokal dalam beternak babi. Papua sangat berpotensi untuk pengembangan ternak babi khususnya babi lokal karena keadaan sosial budaya masyarakat Papua yang mayoritas beragama non muslim, pasaran ternak babi di Papua cukup baik. Kabupaten Jayawijaya merupakan salah satu wilayah yang masyarakatnya melakukan ternak babi khususnya di Wamena sebagai ibu kota Jayawijaya, karean babi merupakan harta yang digunakan untuk menyelesaikan berbagai permasalahan budaya atau acara adat.

Pada pengembangan peternakan babi belum diketahui bagaimaa potensi dan faktor-faktor lingkungan eksternal dan lingkungan internal usaha peternakan babi di Hubikiak Kabupaten Jayawijaya dan Bagaimana strategi pengembangan usaha peternakan babi di Distrik Hubikiak Kabupaten Jayawijaya. Tujuan dari penelitian ini adalah mengidentifikasi potensi dan faktor-faktor lingkungan eksternal dan lingkungan internal usaha peternakan babi di Hubikiak Kabupaten Jayawijaya dan Merumuskan strategi pengembangan usaha peternakan babi di Distrik Hubikiak Kabupaten Jayawijaya. Penelitian ini dilakukan di Distrik Hubikiak Kabupaten Jayawijaya pada bulan Juli sampai pada bulan September 2017. Jumlah responden sebanyak 25 orang yang berasal dari pelaku peternakan babi di Distrik Hubikiak Kabupaten Jayawijaya. Data dikumpukan adalah data primer dan data sekunder. Data di analisis dengan menggunakan analisis SWOT.

Hasil penelitian menunjukkan bahwa, identifikasi faktor-faktor internal dan eksternal yang mempengaruhi pengembangan usaha peternakan babi di Distrik Hubikiak Kabupaten Jayawijaya. ditemukan 8 faktor yang terdiri dari faktor kekuatan internal budaya, pakan lokal, harga dan bibit unggul, faktor kelemahan internal terdiri dari faktor modal, manajemen usaha peternakan, tingkat SDM, erkandangan, faktor peluang eksternal terdiri dari faktor pasar, dukungan dari pemerintah, jenis babi lain/babi non lokal, pesta budaya, sedangkan faktor ancaman eksternal terdidri dari faktor produk daging babi dari luar, penigkatan biaya, pencurian, dan penyakit. Strategi pengembangan usaha peternakan babi dapat menggunakan strategi SO ialah, memiliki budaya yang kuat dan berkaitan erat dengan ternak babi, tentunya peluang dalam pemanfaatan pasar yang cukup tersedia dengan harga babi yang mahal. Ketersediaan pakan lokal untuk mendukung usaha ternak babi, dan penggunaan bibit unggul, yang diharapakan adanya dukukungan dari pemerintah daerah lebih maksimal seperti peningkatan kapasitas SDM, bantuan pakan tambahan, bibit unggul dan penyuntikan ternak.
\end{abstract}

Keywords : Strategi, Pengambangan, Ternak Babi

\section{PENDAHULUAN}

Indonesia memiliki populasi babi terkonsentrasi pada beberapa daerah antara lain di Bali, Sumatera, Jawa, Bali, Kalimantan, Nusa Tenggara Timur (NTT), Sulawesi dan Papua,(BPS RI dan Direktorat Jenderal Peternakan dan Kesehatan, 2017).Usaha peternakan babi di Indonesia telah lama dikenal masyarakat. Agar usaha ini dapat memberikan keuntungan yang optimal bagi pemiliknya maka perlu diperhatikan beberapa hal yang menyangkut Manajemen pemeliharaan ternak babi. Melalui pengamatan dan penelitian yang cukup panjang dalam kehidupan manusia, ternyata babi merupakan hewan yang memenuhi syarat dapat cepat berkembang biak dan daspat menghasilkan daging yang lebih dari 
memadai bila dikelola secara baik berdasarkan tatalaksana peternakan yang mapan, sesuai dengan perkembangan ilmu beternak hasil pengalaman dan penelitian yang telah berjalan ribuan tahun. Keunggulan babi sebagai ternak potong untuk pnyediaan daging babi manusia telah diakui seluruh dunia.

Daerah kantong ternak babi di Indonesia salah satunya adalah Provinsi Papua karena mayoritas masyarakatnya sebagai pengomsumsi daging babi. Papua sangat berpotensi untuk pengembangan ternak babi khususnya babi lokal karena keadaan sosial budaya masyarakat Papua yang mayoritas beragama non muslim, pasaran ternak babi di Papua cukup baik, serta secara sosial budaya masyarakat Papua selalu menggunakan ternak babi terutama babi lokal dalam setiap perayaan adat atau keagamaan. Kabupaten Jayawijaya merupakan salah satu wilayah yang masyarakatnya melakukan ternak babi khususnya di Wamena sebagai ibu kota Jayawijaya. Nama kota Wamena diartikan babi jinak yang mana daerah Wamena dapat dijumpai babi-babi jinak milik masyarakat lokal.

Dilihat dari kondisi alam dan potensi sumber daya alam, Papua secara umum merupakan daerah yang sangat potensial bagi pengembangan peternakan. Beberapa komoditi ternak yang umumnya dipelihara di wilayah Papua adalah sapi, ayam, kambing dan ternak babi. Ternak babi adalah komoditas yang paling digemari bagi masyarakat Papua, sejalan dengan budaya masyarakat Papua (Gobai, 2011). Wamena merupakan wilayah pegunungan bagian tengah Papua, terdapat banyak babi yang diternak secara tradisional oleh mayoritas masyarakat asli pegunungan tengah Papua. Ternak babi lokal mempunyai potensi untuk dikembangkan karena memiliki beberapa keunggulan dibanding babi ras, yakni; pengelolaanya sederhana, toleran terhadap sembarang makanan, lebih tahan terhadap penyakit dan sangat cocok diusahakan di pedesaan (Aritonang,1993).

Usahatani peternakan babi sebagai mata pencaharian andalan masyarakat Papua harus dikelola lebih intensif dalam skala rumah tangga. Kondisi peternakan babi saat ini di Papua masih berada pada tahapan yang subsisten (Awon, 2010; Iyai, 2008; Marani, 2004) yang juga menurut Soharto (1990) masuk dalam kategori usahatani tradisional.

Usaha peternakan babi sebagai mata pencaharian andalan masyarakat Papua harus dikelola lebih intensif dalam skala rumah tangga. Kondisi peternakan babi saat ini di Papua masih berada pada tahapan yang subsisten (Awon, 2010; Iyai, 2008; Marani, 2004), yang juga menurut Soharto (1990) masuk dalam kategori usahatani tradisional. Terdapat beberapa keuntungan yang dapat diperoleh dalam beternak babi, selain sebagai sumber protein juga dapat memberikan sumbangan yang besar bagi peningkatan pendapatan keluarga peternak. Upaya peningkatan keuntungan membutuhkan perhitungan penggunaan biaya faktor produksi dalam usaha ternak babi, dalam pengembangan usaha peternakan babi. Khususnya di daerah Kabupaten Jayawijaya yang mayoritas masyarakat melakukan peternakan babi secara tradisional yang harus dikembangkan untuk menjadi pelaku peternakan yang memiliki perencanaan dalam mencapai keuntungan yang lebih dimasa yang akan datang.

\section{METODE PENELITIAN}

Penentuan lokasi peneliatian dilakukan secara sengaja (purpossive), di Distrik Hubikiak Kabupaten Jayawijaya dan telah dilakukan pada bulan Juli sampai pada bulan September 2017. Penentuan responden dilakukan secara purpossive (sengaja). Responden dipilih dari pihak internal pelaku peternakan babi di Distrik Hubikiak Kabupaten Jayawijaya berjumlah 25 orang dari 3 Kampung sebagai perwakilan sampel ialah kampung Husoak, Kampung Doku dan Kampung Hubikiak, yang mendukung pengumpulan data-data dalam penelitian.

Jenis dan sumber data yang digunakan dalam penelitian ini menggunakan dua jenis data, meliputi : 
1. Data primer yaitu data yang diperoleh secara langsung dari responden, baik melalui wawancara langsung kepada responden/pelaku ternak babi melalui pengisian dengan menggunakan daftar pertanyaan (Questionnaire).

2. Data sekunder diperoleh dari instansiinstansi terkait seperti Dinas Pemerintah terkait seperti Dinas Pertanian dan Badan Pusat Statistik (BPS) Kabupaten Jayawijaya, serta sumber-sumber penunjang lainnya didapat dari situs internet, artikel majalah, surat kabar, penelitianpenelitian terdahulu yang ada kaitannya dengan penelitian ini, sebagai pendukung dalam penyusunan hasil penelitian.

Pencapaian tujuan penelitian ini dilakukan dengan menggunakan analisis deskriptif kualitatif dan analisis SWOT. Analisis SWOT ini akan mengidentifikasikan faktor internal dan eksternal usaha peternakan babi. Dari sisi internal akan dilihat kekuatan atau kelemahan yang dimiliki oleh usaha peternakan babi itu sendiri. Sedangkan dari sisi eksternal, akan dilihat peluang dan ancaman dari luar usaha. Setelah mengidentifikasi faktor-faktor tersebut, dilakukan perumusan terhadap strategi dengan menggunakan diagram SWOT sebagai berikut (Rangkuti, 2009).

\section{HASIL DAN PEMBAHASAN \\ Gambaran Umum Lokasi Penelitian}

Distrik Hubikiak adalah Distrik Pemekaran dari Distrik Hubikosi yang terletak sebelah Timur yang berbatasan langsung dengan Ibu kota Kabupaten Jayawijaya dan Distrik Hubikiak terdiri dari 8 kampung yaitu : Kampung HomHom, Kampung Musiaima II, Kampung Hetuma, Kampung Dokopku, Kampung Likino, Kampung Musiaima, Kampung Hubikiak, dan Kampung Husoak.

Distrik Hubikiak mempunyai arti : Kata Hubi adalah yang artinya sekelompok suku Huby, Kiak artinya tangan tidak baik, yang artinya suku Hubi suka melakukan tindakan kerasan, mencuri, merampok, dan membunuh orang tanpa konpromi terhadap orang lain sehingga Distrik Hubikiak disegani oleh semua suku yang ada di kabupaten Jayawijaya sehingga pemerintah Kabupaten Jayawijaya berdasarkan peraturan Daerah Nomor :26 tahun 2009 mendirikan Distrik Hubikiak hingga sampai sekarang. Adapun kesenian dari Distrik Hubikiak adalah tarian pesek dan tarian perang-perangan yang merupakan bagian dari budaya masyarakat setempat memiliki budaya unik dan asli. Potensi yang ada di Distrik Hubikiak ialah pertanian, perikanan, dan peternakan.

Letak batas wilayah Distrik Hubikiak sebagai berikut :

Sebelah barat Distrik Palebaga

Sebelah Timur Distrik Witawaya

Sebelah Utara Distrik Musalfak

Sebelah Selatan Wamena Kota

\section{Keadaan Penduduk dan Pertanian Distrik Hubikiak}

Berdasarkan data tahun 2014 penduduk di Distrik Hubikiak ialah berkisar 8.738 jiwa, dengan berbagai latar pekerjaan dan beragam agama, suku baik lokal maupun nonlokal. Penduduk di Distrik Hubikiak pada umumnya bekerja sebagai petani dan ternak babi.

Kondisi pertanian di daerah Distrik Hubikiak Kabupaten Jayawijaya memiliki berbagai ragam kegiatan usaha pertanian seperti tanaman pangan dan hortikultura, perikanan serta peternakan yang pada umumnya babi.

\section{Karakteristik Responden Penelitian}

Karakteristik responden merupakan gambaran atau keadaan responden berdasarkan observasi dan wawancara yang menjadi sumber informasi dalam penelitian ini terdiri dari umur, tingkat pendidikan, jumlah tanggungan keluarga dan pengalaman usaha.

Umur merupakan salah satu faktor yang cukup dominan dalam pembentukan kerja sesorang, hal tersebut akan 
berpengaruh terhadap kemampuan dan keterampilannya. Demikian pula dalam kegiatan usahtani, umur petani sangat berpengaruh terhadap kemampuan kerja dan sikapnya dalam mengelolah usahanya. Pada umumnya petani yang berumur lebih muda akan memiliki kemampuan fisik yang relatif besar, semangat kerja yang tinggi, dan berjiwa dinamis, sehingga lebih cepat dalam menerima teknologi baru yang bertujuan untuk meningkatkan produksi dan pendapatan. Pelaku usahatani yang lebih muda akan cenderung melakukan perubahan penggunaan input-input baru dalam produksi jika dibandingkan dengan mereka yang lebih tua, karena pembudidaya yang berumur relatif muda menghendaki adanya perubahan yang terjadi untuk keberhasilan usahanya.

Tabel 1. Karakteristik Responden Berdasarkan Tingkat Umur Usaha Peternakan Babi

\begin{tabular}{ccc}
\hline Tingkat Umur & $\begin{array}{c}\text { Jumlah } \\
\text { Responden }\end{array}$ & Persentase \\
\hline$<30$ & 3 & $12 \%$ \\
$30-50$ & 20 & $80 \%$ \\
$>50$ & 2 & $8 \%$ \\
\hline Jumlah & $\mathbf{2 5}$ & $\mathbf{1 0 0 \%}$ \\
\hline
\end{tabular}

Sumber : Data Primir Diolah 2017

Tabel 1, menunjukkan bahwa tingkat umur responden usaha peternakan babi didominasi tingkat umur antara 30-50 tahun $(80 \%)$ yang berada pada usia produktif dalam bekerja. Umur responden berdasarkan Tabel 3 masi berada pada umur produktif, sesuai dengan pernyataan Badan Pusat Statistik bahwa usia 15-64 tahun dinamakan usia kerja atau usia produktif dalam melakukan kegiatan usahanya. Pelaku usaha yang berumur tua memiliki kemampuan fisik yang relatif rendah, namun di sisi mereka lebih berpengalaman dalam melakukan usahanya.

Pendidikan adalah sebagai usaha sadar dan terencana untuk mewujudkan suasana belajar dan proses pembelajaran untuk peserta didik secara aktif mengembangkan potensi dirinya untuk memiliki kekuatan spiritual keagamaan, pengendalian diri, kepribadian, kecerdasan, akhlak mulia, serta keterampilan yang diperlukan dirinya dan masyarakat. Berdasarkan UU. No.20 Tahun 2003 mengenai Sistem Pendidikan Nasional dalam pasal 3, bahwa tujuan pendidikan nasional adalah mengembangkan potensi peserta didik agar menjadi manusia yang beriman dan bertakwa kepada Tuhan Yang Maha Esa, berakhlak mulia, sehat, berilmu, cakap, kreatif, mandiri, dan menjadi warga negara yang demokratis serta bertanggung jawab. Pendidikan dapat diperoleh baik secara formal dan non formal. Pendidikan secara formal diperoleh dengan mengikuti program-program yang telah direncanakan, terstruktur oleh suatu insititusi, departemen atau kementtrian suatu negara seperti di sekolah pendidikan memerlukan sebuah kurikulum untuk melaksanakan perencanaan penganjaran. Sedangkan pendidikan non formal adalah pengetahuan yang diperoleh dari kehidupan sehari-hari dari berbagai pengalaman baik yang dialami atau dipelajari dari orang lain.

Tabel 2. Karakteristik Berdasarkan Tingkat Pendidikan Petani Usaha Peternakan Babi

\begin{tabular}{ccc}
\hline Tingkat Pendidikan & $\begin{array}{c}\text { Jumlah } \\
\text { Responden }\end{array}$ & Persentase \\
\hline Non Pendidikan & 5 & $20 \%$ \\
SD & 1 & $4 \%$ \\
SMP & 3 & $12 \%$ \\
SMA & 11 & $44 \%$ \\
Sarjana & 5 & $20 \%$ \\
Jumlah & $\mathbf{2 5}$ & $\mathbf{1 0 0 \%}$
\end{tabular}

Sumber : Data Primer Diolah 2017

Tingkat pendidikan responden berdasarkan pada Tabel 2 menunjukkan bahwa, responden didominasi dengan tingkat pendidikan SMA ialah $44 \%$ sedangkan $20 \%$ untuk responden yang berpendidikan sarjana dan tidak memiliki pendidikan atau putus sekolah, responden berpendidikan SMP hanya $12 \%$ dan $4 \%$ untuk tingkat pendidikan SD. Tabel 4 menggambarkan tingkat pendidikan yang dimiliki responden usaha peternakan babi, 
dianggap mampu mengembangkan usahanya melalui penambahan kapasitas pengetahuan manajemen pengolahan usaha peternakan babi kemasa yang akan datang.

Jumlah tanggungan keluarga dari setiap kepala keluarga ditentukan oleh banyaknya anggota keluarga yang menjadi tanggung jawab kepala keluarga tersebut. Jumlah tanggungan keluarga merupakan salah satu faktor yang dapat mempengaruhi usaha peternakan babi, semakin banyak jumlah tanggungan maka ketersediaan tenaga keluarga juga cukup tersedia.

Tabel 3. Karakteristik Petani Berdasarkan Jumlah Tanggungan Keluarga Usaha Peternakan Babi

\begin{tabular}{|c|c|c|}
\hline $\begin{array}{c}\text { Jumlah } \\
\text { Tanggungan }\end{array}$ & $\begin{array}{c}\text { Jumlah } \\
\text { Responden } \\
\end{array}$ & Persentase \\
\hline$<4$ & 11 & $44 \%$ \\
\hline $4-6$ & 9 & $36 \%$ \\
\hline \multirow[t]{2}{*}{$>6$} & 5 & $20 \%$ \\
\hline & 2 & $100 \%$ \\
\hline
\end{tabular}

Sumber : Data Primer Diolah 2017

Tabel 3, menunjukkan bahwa jumlah tanggungan keluarga berada dibawah $4(<4)$ orang tanggungan/kepala keluarga sebesar $44 \%$

dari jumlah responden. Untuk jumlah tanggungan di atas $6(>6)$ orang/kepala keluarga dominan sedikit ialah $20 \%$.

Pengalaman usaha artinya seberapa besar kita telah menjalani atau melakukan usaha tersebut, dalam hal usaha peternakan babi. Pada umumnya semakin lama responden melakukan usahanya maka semakin banyak pengalaman yang didapatkan seperti, masalah-masalah, pengetahuan dan kemampuan untuk mengembangkan usahanya.

Tabel 4. Karakteristik Pengalaman Usaha Peternakan

\begin{tabular}{ccc}
\hline Tingkat Pengalaman & Jumlah Petani & Persentase \\
\hline$<5$ & 6 & $24 \%$ \\
$>5$ & 19 & $76 \%$ \\
\hline & $\mathbf{2 5}$ & $\mathbf{1 0 0} \%$ \\
\hline
\end{tabular}

Sumber : Data Primer Diolah 2017

Berdasarkan data pada Tabel 4, bahwa pengalaman responden dalam melakukan kegiatan atau menjalankan usaha peternakan babi di Distrik Hubikiak Kabupaten Jayawijaya antara $<5$ tahun $(24 \%)$ dan $<5(76 \%)$ artinya responden memiliki pengalaman yang lebih banyak ialah di atas 5 tahun. Hal ini berarti bahwa dengan pengalaman yang dimiliki oleh responden, tentunya mempunyai kemampuan yang lebih baik dalam mengembangkan usaha peternakannya yang lebih maksimal.

\section{Gambaran Umum Peternakan Babi}

Ada tiga cara pelestarian pada babi lokal yang dapat dilakukan menurut PP Nomor 48 Tahun 2011 adalah dengan cara (1) Menetapkan wilayah budaya Dan pengembangan babi lokal wilayah kabupaten/kota ;(2) Mempertahankan keberadaan dan kemanfaatan lahan penggembalaan umum untuk budidaya babi lokal; serta (3) Mengembangkan dan meningkatkan produktivitas babi lokal.Pada babi lokal yang telah diternakkan oleh masyarakat, maka pelestarian dilakukan dengan melakukan seleksi dalam rumpun agar kemurnian tetap dipertahankan dan konservasinya melalui usaha perbaikan pengelolaan ternak babi lokal (Chamdi, 2005). Berdasarkan Permentan Nomor 117 Tahun 2014 disebutkan bahwa pola pelesatarian lainnya adalah dengan cara membangun dan mengembangkan sistem pembibitan ternak di pedesaan (village breeding center) pada kawasan yang secara sosioal budaya senang pada ternak babi. Pola pembibitan dilakukan dengan mengandalkan swadaya masyarakat, khususnya para peternak babi lokal dengan pola kemitraan yang mengandalkan kerjasama antara perusahaan dengan peternak babi lokal dalam sistem inti-plasma (Chamdi 2005). Dua pola pelestarian dan pengembangan tersebut dapat diterapkan dalam pengembangan bibit Babi lokal yang potensial seperti babi lokal yang diternakkan oleh para peternak seperti babi Bali,Timor, Toraja dan Wamena.

Berdasarkan hasil penelitian dan didukung berbagai sumber bahwa budaya yang ada di tanah Papua tepatnya di wilayah 
Pegunungan Tengah Papua Kabupaten Jayawijaya tak terpisakan dari ternak babi. Babi merupakan bagian dari budaya di Papua, yang kenal dan sangat populer, misalnya dalam menyelesaikan suatu permasalahan,lamaran, dan acara-acara lainnya pasti menggunakan babi. Peternakan babi saat ini masih dilakukan secara tradisional dan masih banyak yang belum menerapkan sistem perkandagan, yang mana masih diternakkan secara liar/terbuka. Ada 2 jenis babi yang dibudidayakan atau diternak di Kabupaten Jayawijaya ialah babi lokal Wamena diternak oleh masyarakat lokal dan jenis babi Toraja yang pada umumnya diternak oleh masyarakat non lokal (Toraja).

Tanaman ubi jalar dengan kata lain hipere merupakan nama tanaman ubi jalar yang populer di masyarakat Pegunungan Tengah Papua, yang mana daunnya digunakan sebagai pakan utama ternak babi, dan umbinya sebagai bahan makanan pokok utama masyarakat lokal. Babi juga tak terpisahkan dengan tanaman hipere/ubi jalar, karena sama-sama bagian dari budaya lokal Papua. Permintaan pasar juga sangat besar utamanya saat adanya hari-hari tertentu setiap tahunnya, seperti hari perayaan natal dan tahun baru. Berdasarkan hasil observasi terhadap peternakan babi di Kawasan Pegunugan Tengah Papua memiliki nilai ekonomis yang sangat tinggi yang berkisaran $\mathrm{Rp} 2.000 .000$ untuk anak babi 2-3 bulan dan Rp 15.000.000 hingga Rp. 30.000.000 untuk babi besar, ukuran babi juga menentukan besar tinggi rendahnya harga. Dari 30 responden peternakan babi di Distrik Hubikiak ratarata memiliki 8 ekor tenak babi.

\section{Hasil identifikasi Faktor Internal dan Eksternal}

Berdasarkan hasil identifikasi dengan melakukan wawancara dan survei langsung terhadap responden maka ditemukan beberapa indikator menggambarkan faktor internal dan eksternal yaitu kekuatan, kelemahan, peluang dan ancaman yang mempengaruhi pengembangan usaha peternakan babi di Distrik Hubikiak Kabupaten Jayawijaya.

Analisis lingkungan internal kekuatan (Strengths) pada pengembangan strategi usaha peternakan babi teridentifikasi atas 4 indikaator penting sebagai berikut :

1. Budaya

Budaya salah satu faktor utama yang dimiliki oleh masyarakat lokal pada umumnya terindentifikasi sebagai pengaruh yang kuat dalam melakukan usaha peternakan, yang mana memiliki nilai bobot 0,12 yang mana sama pentingnya dengan faktor pakan lokal, namun memiliki kondisi yang berbeda yaitu rating budaya 4 dan pakan lokal 3 . Artinya kedua faktor tersebut sama penting, namun kondisi atau keadaanya berbeda, kondisi budaya lebih dominan pengaruhnya terhadap peternakan babi dibandaing faktor pakan lokal. Jika dilihat pada Tabel 5, faktor budaya dan faktor harga sama-sama memiliki kondisi yang sama dan pengaruh yang sama terhadap kegiatan usaha peternakan babi, yang mana memiliki nilai rating 4 , namun memiliki tingkat kepentingan yang tidak sama.

2. Pakan lokal

Pakan lokal merupakan pakan utama untuk peternakan babi, yaitu dari daun ubi jalar yang banyak dibudidayakan di Distrik Hubikiak atau di Wilaya Kabupaten Jayawijaya. Faktor pakan lokal teridentifikasi sebagai salah satu faktor yang berpengaruh terhadap usaha peternakan babi memiliki bobot sebesar 0,12 yang sama pentingnya dengan faktor budaya juga memiliki bobot sebesar 0,12. Faktor tersebut adalah faktor yang memiliki nilai bobot/tingkat kepentingan terendah dari faktor kekuatan internal lainnya, namun faktor budaya memiliki kondisi yang lebih dominan berpengaruh terhadap usaha peternakan babi yang mana memiliki rating tertinggi sebesar 4, sedangkan faktor pakan lokal memiliki rating 3 .

3. Harga 
Harga teridentifikasi sebagai faktor yang merupakan salah satu penentu utama kegiatan usaha peternakan babi, karena harga termasuk faktor yang mempengaruhi masyarakat untuk beternak. Besar kecilnya harga babi menentukan besar kecilnya keuntungan bagi pelaku usaha peternakan babi ketika menjual hasil ternaknya. Tabel 7, menggambarkan faktor harga memiliki nilai bobot sebesar 0,15 ialah nilai tingkat kepentingan terhadap usaha peternakan babi. Dengan nilai bobot tertinggi dari faktor kekuatan lainnya sebesar 0,15 , dan nilai rating sebesar 4, artinya kondisi faktor sangat dominan atau sama dominannya dengan faktor budaya yang mempengaruhi pengembangan usaha peternakan babi.

4. Bibit unggul

Bibit merupakan anak babi yang dipersiapakan untuk dibudidayakan, dalam usaha peternakan, bibit dianggap penting. Bibit unggul dapat diperoleh melalui ternak sendiri yaitu perkawinan silang antara babi lokal dan babi non lokal seperti babi toraja yang memiliki postur tubuh yang lebih besar dan cepat besar jika dibandingkan babi lokal. Bibit teridentifikasi sebagai faktor yang berpengaruh terhadap usaha peternakan babi memiliki bobot/tingkat kepentingan sebesar 0,13 dimana lebih penting pengaruhnya dibanding faktor kekuatan lainnya ialah faktor budaya dan faktor pakan lokal yang memiliki bobot sebesar 0,12 . Nilai rating 2 merupakan nilai rating terendah dibanding nilai rating faktor kekuatan internal lainnya, artinya faktor bibit ini memiliki kondisi yang belum dietrapkan secara maksimal, atau masih rendahnya pengetahuan tetang perkawinan silang ternak babi untuk memperoleh bibit unggul yang lebih baik.

\section{Analisis lingkungan internal} kelemahan (Weakness) pada pengembangan strategi usaha peternakan babi teridentifikasi atas 4 indikaator penting sebagai berikut :

\section{Modal}

Modal merupakan salah satu faktor utama dalam melakukan setiap usaha, secara khusus untuk peternakan babi, tentunya membutuhkan jumlah modal berupa uang yang besar, baik dalam penyiapan kandang, pakan dan bibit. Modal teridentifikasi sebagai faktor kelemahan internal yang di anggap sangat mempengaruhi kegiatan usaha peternakan babi di Distrik Hubikiak Kabupaten Jayawijaya. Faktor modal memiliki bobot/tingkat kepentingan paling tinggi ialah 0,15 yang mana faktor yang paling penting dari faktor kelemahan internal lainnya, disajikan pada Tabel 7. Modal memiliki rating sebesar 3 artinya kondisi faktor yang dialami responden/pelaku usaha peternakan babi cukup berpengaruh terhadap pengembangan peternakannya, dimana rata-rata peternak masih keterbatasan modal.

2. Manajemen usaha peternakan

Usaha peternakan memerlukan kecakapan manajemen agar usaha dapat menguntungkan. Seorang pengusaha atau yang melakukan usaha mempunyai keahlian manajemen maka akan dapat bertahan apabila menghadapi perubahanperubahan yang selalu terjadi dalam dunia usahanya. Manajemen merupakan patokan utama dalam mencapai suatu tujuan ialah keuntungan dari usaha peternakan yang dilakukan, sehingga faktor manajemen usaha peternakan teridentifikasi sebagai faktor yang mempengaruhi pengembangan usaha. Tabel 5, menunjukkan bahwa nilai bobot/tingkat kepentingan sebesar 0,12 yang sama pentingnya dengan faktor SDM yang harus diterapkan dan dikembangkan sehingga tidak menjadi kelemahan internal usaha peternakan babi. Nilai rating 2 artinya kondisi faktor manajemen usaha peternakan belum diterapkan, sehingga menjadi faktor kelemahan usaha.

3. Peningkatan SDM

Sumber daya manusia (SDM) merupakan suatu hal yang sangat penting dan harus dimiliki dalam upaya mencapai tujuan kegiatan usaha. Sumber daya manusia merupakan elemen utama dibandingkan dengan elemen sumber daya yang lain seperti modal, teknologi, karena manusia 
itu sendiri yang mengendalikan faktor yang lain. Oleh karena itu, perlunya suatu kualitas atau manajemen sumber daya manusia merupakan program aktivitas untuk mengembangkan,memelihara, merencanakan , mengatur dan sebagainya untuk mencapai tujuan. Sumber daya manusia teridentifikasi sebagai faktor yang mempengaruhi pengembangan usaha peternakan babi yang mana memiliki bobot/tingkat kepentingan sebesar 12, sama pentingnya dengan faktor manajemen usaha peternakan. Kondisi faktor tersebut juga belum diterapkan sehingga memiliki nilai rating 2 , artinya faktor tersebut harus diterapkan dan dikembangkan pada usaha peternakan babi, sehingga menjadikan faktor kekuatan internal.

4. Perkandangan

Kandang merupakan salah satu kebutuhan penting dalam usaha peternakan karena struktur atau bangunan di mana hewan ternak dipelihara. Fungsi utama kandang adalah untuk menjaga supaya ternak tidak berkeliaran dan memudahkan pemantauan serta perawatan ternak. Terdapat banyak sekali jenis kandang, baik berdasarkan tipe maupun bahan yang digunakan untuk membuat kandang tersebut, sedangkan penggunaannya disesuaikan dengan kebutuhan. secara tidak langsung kandang juga mempengaruhi kualitas dan kuantitas hasil peternakan. Perkandangan teridentifikasi sebgagai faktor yang mempengaruhi usaha peternakan babi, dengan bobot/tingkat kepentingan sebesar 0,09 yang tersaji pada Tabel 5, dan memiliki rating sebesar 2 , artinya faktor ini memiliki nilai bobot paling sedikit dari faktor kelemahan internal lainnya, namun penerapan kandang sangat penting dalam usaha peternakan babi. Dari hasil observasi terhadap responden belum semuanya menerapkan sistem perkandangan terhadap ternaknya sehingga mendapatkan nilai rating 2 , yang menjadikan faktor tersebut berada pada kelemahan internal.
Setelah faktor-faktor internal yang mempengaruhi usaha peternakan babi terindentifikasi, selanjutnya dibuat dalam tabel IFAS (Internal Factor Analisis Summary). Berdasarkan dari hasil perhitungkan setiap rating, maka diperoleh pembobotan untuk masing-masing nilai rating faktor internal yang disajikan pada Tabel 5 .

Tabel 5. Analisis SWOT matriks (IFAS)

\begin{tabular}{|c|c|c|c|}
\hline FAKTOR INTERNAL & $\begin{array}{c}\text { Bobo } \\
\mathbf{t} \\
\end{array}$ & $\begin{array}{c}\text { Ratin } \\
\mathbf{g}\end{array}$ & $\begin{array}{c}\text { bobot } X \\
\text { Rating } \\
\end{array}$ \\
\hline \multicolumn{4}{|l|}{ Kekuatan } \\
\hline Budaya & 0,12 & 4 & 0,48 \\
\hline Pakan Lokal & 0,12 & 3 & 0,36 \\
\hline Harga & 0,15 & 4 & 0,60 \\
\hline Bibit unggul & 0,13 & 2 & 0,26 \\
\hline Sub Total & 0,52 & & 1,70 \\
\hline \multicolumn{4}{|l|}{ Kelemahan } \\
\hline Modal & 0,15 & 3 & 0,45 \\
\hline Manajemen usaha peternakan & 0,12 & 2 & 0,24 \\
\hline Tingkat SDM & 0,12 & 2 & 0,24 \\
\hline Perkandangan & 0,09 & 2 & 0,18 \\
\hline Sub Total & 0,48 & 22 & 1,11 \\
\hline Total $(1+2)$ & 1,00 & & 2,81 \\
\hline
\end{tabular}

Sumber : Data Primer Setelah Diolah 2017.

Kooifisien IFAS bernilai 2.81> 2,0 maka usaha dapat merespon perubahan faktor-faktor internal yang mempengaruhi lingkungannya. Berdasarkan hasil analisis Internal Faktor Analysis Summary (IFAS) pada Tabel 5, menunjukkan faktor kekuatan (Strengths) memiliki nilai lebih besar yaitu 1,70 dibanding dengan nilai faktor kelemahan (Weakness) yang bernilai 1,11 . Hal ini dapat diartikan bahwa kekuatan yang dimiliki oleh usaha peternakan babi dapat memaksimalkan faktor kekuatan yang ada untuk meminimalkan faktor-faktor kelemahannnya.

Tabel 5 menggambarkan bobot faktor internal ialah tingkat kepentingan faktor yang teridentifikasi terhadap usaha peternakan babi, sedangkan nilai rating faktor internal ialah kondisi faktor terhadap usaha peternakan babi berdasarkan keadaan yang sebenarnya. Faktor pengembangan strategi uasaha peternakan babi berdasarkan perhitungan dari nilai rating faktor internal ialah pengurangan antara faktor kekuatan (Strengths) dan kelemahan (Weakness) yaitu $1,70-1,11=0,59$ dijadikan titik koordinat pada sumbu $X$. 


\section{Analisis Lingkungan Eksternal peluang (Opportunities)}

Analisis lingkungan eksternal untuk mengidentifikasi faktor peluang (Opportunities) yang ada pada pengembangan strategi usaha peternakan babi teridentifikasi atas 4 indikaator penting sebagai berikut :

1. Pasar

Pasar merupakan tempat untuk menjual hasil produksi atau tempat transaksi pertukaran barang dan jasa dengan uang. Pasar merupakan fasilitas yang tersedia sebagai tempat menjual hasil ternak, sehingga teridentifikasi sebagai faktor peluang eksternal yang mempengaruhi kegiatan usaha peternakan babi dengan nilai bobot/tingkat kepentingan sebesar 0,14. Faktor pasar diberi rating sebesar 4, karena berdasarkan hasil survei pasar sebagai tempat memasarkan hasil peternakan babi sangat tersedia yang terdapat di pasar Baru Wamena, letaknya tidak jauh dari Distrik Hubikiak.

2. Dukungan dari pemerintah

Dukungan pemerintah dalam hal ini ditinjau dari berbagai kebijakan terhadap pelaku usaha peternakan babi, baik dalam bentuk penyuluhan, pelatihan, pemberian bantuan langsung baik berupa dana, pakan, ataupun bibit unggul. Faktor adanya dukungan dari pemerintahan setempat teridentifikasi sebagai faktor peluang yang diharapkan pelaku usaha peternakan babi di Distrik Hubikiak, maka diberikan bobot sebesar 0,14 , artinya sama pentingnya dengan faktor harga atau lebih penting dari faktor peluang eksternal lainnya untuk menunjang kegiatan usaha peternakan babi. Pemberian rating sebesar 2 berdasarkan hasil observasi terhadap 25 responden bahwa faktor dukungan dari pemerintah belum maksimal atau kurang tersedia dalam menunjang kegiatan usaha peternakan babi di Distrik Hubikiak.

3. Jenis babi lain/babi non lokal
Jenis babi lain ialah babi non lokal seperti babi toraja atau babi jenis lainnya, yang dapat menjadiakan peluang bagi usaha peternakan babi untuk memperoleh bibit unggul melalui perkawinan silang. Faktor ini teridentifikasi sebagai faktor peluang eksternal usaha dengan pemberian bobot sebesar 0,13, artinya cukup penting diterapkan dalam kegiatan usaha peternakan babi. Pemberian rating sebesar 3, artinya kondisinya memungkinkan karena jenis babi non lokal cukup tesedia seperti babi toraja yang banyak di budidayakan oleh masyarakat non lokal.

4. Pesta budaya

Pesta budaya merupakan acara adat yang sering dilakukan oleh masyarakat lokal Papua di pegunungan tengah Papua yang menggunakan babi, seperti pernikahan atau lamaran, bakar batu, syukuran ibadah dan bayar denda jika ada permasalahan. Faktor ini cukup mempengaruhi usaha peternakan babi yang menjadikan suatu peluang eksternal sehingga diberi rating sebesar 0,09, artinya di anggap sedikit penting dari faktor peluang eksternal lainnya, namun memiliki nilai rating sebesar 3 dimana kondisi tersebut sering dilakukan oleh masyarakat lokal pada umumnya di wilayah pegunungan tengah Papua.

\section{Analisis Lingkungan Eksternal ancaman (Treaths)}

Analisis lingkungan eksternal untuk mengidentifikasi faktor ancaman (Treaths) yang ada pada pengembangan strategi usaha peternakan babi teridentifikasi atas 4 indikaator penting sebagai berikut :

1. Produk daging babi dari luar

Produk daging babi dari luar teridentifikasi sebagai faktor ancaman eksternal usaha peternakan babi sehingga diberi bobot sebesar 0,13 , artinya cuku penting dan serius bisa menjadi dampak, menggeser nilai/harga produk daging babi lokal, karena lebih murah. 
Pemeberian rating sebesar 2, artinya kondisi tersebut belum terlalu berpengaruh hingga saat ini, namun faktor tesebut bisa menjadi ancaman bagi produk daging atau babi lokal yang dibudidayakan di Kabupaten Jayawijaya secara khusus Distrik Hubikiak.

2. Peningkatan biaya

Peningkatan biaya teridentifikasi sebagai faktor ancaman eksternal terhadap usaha peternakan babi, dengan pemberian bobot sebesar 0,11 merupakan bobot terkecil dari faktor ancaman eksternal lainnya, namun penting diperhitungkan dalam melakukan usaha agar tidak rugi. Peningkatan biaya berdasarkan pemberian rating sebesar 2, artinya faktor ini memiliki kondisi yang jarang terjadi, namun ketika terjadi kenaikan biaya akan menjadi sebuah ancaman, misalnya kenaikan harga pakan campuran, maupun lokal.

3. Pencurian

Pencurian merupakan faktor yang teridentifikasi sebagai faktor ancaman eksternal usaha peternakan babi yang penting dengan bobot sebesar 0,12 , yang mana sedikit lebih penting dari faktor peningkatan biaya. Pemberian rating sebesar 3, artinya menggambarkan kondisi yang sering terjadi ketika pelaku usaha peternakan lalai. Hal ini terjadi karena harga babi juga sangat mahal sehingga membuat pencuri beraksi, faktor ini memberikan ancaman ekternal terhadap usaha peternakan babi.

4. Penyakit

Berdasarkan hasil observasi terhadap 25 responden mengatakan bahwa penyakit sering menyerang ternak babi, ialah cacing pita dan kutu babi (gatal-gatal pada babi). Penyakit teridentifikasi sebagai faktor nacaman eksternal dengan pemberian bobot sebesar 0,14, merupakan nilai bobot paling tinggi atau faktor ini lebih penting dari faktor ancaman eksternal lainnya. Penyakit ini dapat memberikan kerugian, yang membuat ternak sakit dan mati, atau menurunkan kualitas dan mempengaruhi pertumbuhan ternak babi. Pemberian rating sebesar 3, artinya kondisi faktor penyakit sering terjadi atau menyerang ternak babi, yang harus ditindak lanjuti melalui penyuntikan oleh dokter hewan.

Setelah faktor-faktor eksternal usaha peternakan babi terindentifikasi, selanjutnya dibuat dalam tabel EFAS (Eksternal Factor Analisis Summary). Berdasarkan dari hasil perhitungkan setiap rating, maka diperoleh pembobotan untuk masing-masing nilai rating faktor internal yang disajikan pada Tabel 6.

Kooifisien IFAS bernilai 2,76> 2,0 maka perusahaan dapat merespon perubahan faktor-faktor eksternal yang mempengaruhi lingkungannya. Berdasarkan hasil analisis Eksternal Faktor Analysis Summary (EFAS) pada Tabel 6, menunjukkan faktor peluang (Opportunities) memiliki nilai lebih besar yaitu 1,50, dibanding dengan nilai faktor ancaman (Threaths) yang bernilai 1,26. Hal ini dapat diartikan bahwa peluang yang dimiliki oleh kegiatan usaha peternakan dapat memanfaatkan faktor peluang yang ada untuk mengatasi faktor ancaman.

Tabel 6. Analisis SWOT Matriks (EFAS)

\begin{tabular}{|c|c|c|c|}
\hline FAKTOR EKSTERNAL & $\begin{array}{c}\text { Bobo } \\
\mathbf{t}\end{array}$ & $\begin{array}{c}\text { Ratin } \\
\mathbf{g}\end{array}$ & $\begin{array}{c}\text { bobot } \\
\text { X } \\
\text { Rating }\end{array}$ \\
\hline \multicolumn{4}{|l|}{ Peluang } \\
\hline Pasar & 0.14 & 4 & 0.56 \\
\hline Dukungan dari pemerintah & 0.14 & 2 & 0.28 \\
\hline $\begin{array}{l}\text { Jenis babi lain/babi non } \\
\text { lokal }\end{array}$ & 0.13 & 3 & 0.39 \\
\hline Pesta Budaya & 0.09 & 3 & 0.27 \\
\hline Sub Total & 0.50 & 12 & 1.50 \\
\hline $\begin{array}{l}\quad \text { Ancaman } \\
\text { Produk daging babi dari } \\
\text { luar }\end{array}$ & 0.13 & 2 & 0.26 \\
\hline Penigkatan biaya & 0.11 & 2 & 0.22 \\
\hline Pencurian & 0.12 & 3 & 0.36 \\
\hline Penyakit & 0.14 & 3 & 0.42 \\
\hline Sub Total & 0.50 & 10 & 1.26 \\
\hline Total $(1+2)$ & 1.00 & & 2.76 \\
\hline
\end{tabular}

Sumber : Data Setelah Diolah 2017

Tabel 6, menggambarkan bobot faktor eksternal ialah tingkat kepentingan faktor yang teridentifikasi terhadap usaha peternakan babi, sedangkan nilai rating faktor eksternal ialah kondisi faktor 
terhadap usaha peternakan babi berdasarkan keadaan yang sebenarnya. Faktor pengembangan strategi usaha peternakan babi berdasarkan perhitungan dari nilai rating faktor eksternal ialah pengurangan antara faktor peluang (Opportunities) dan ancaman (Threaths) yaitu 1,50-1,26 =0,24 yang dijadikan sebagai sumbu Y. Hasil kualitatif antara faktor internal dan faktor eksternal akan diformulasikan pada diagram SWOT agar dapat diketahui letak kuadran usahanya.

Berdasarkan hasil pembobotan dapat disimpulkan bahwa total skor faktor internal yang diperoleh dari pengurangan total faktor kekuatan dan faktor kelemahan sebagai sumbuh $X$ yaitu 0,95 . Total skor faktor eksternal yang merupakan hasil pengurangan antara total faktor peluang dan total faktor ancaman sebagai sumbu Y yaitu 0,24 seperti pada Tabel 7 .

Tabel 7. Hasil skoring faktor Internal dan faktor Eksternal

\begin{tabular}{lcc}
\hline \multicolumn{1}{c}{ Kriteria } & Koordinat & Keterangan \\
\hline $\begin{array}{l}\text { Faktor Internal } \\
\text { Kekuatan } \\
\text { (Strengths) }\end{array}$ & & \\
$\begin{array}{l}\text { Kelemahan } \\
\text { (Weakness) }\end{array}$ & 0,59 & Sumbu X \\
$\begin{array}{l}\text { Faktor Eksternal } \\
\text { Peluang } \\
\text { (Opportunities) }\end{array}$ & 0,24 & \\
Ancaman (Treaths) & & Sumbu $Y$ \\
\hline
\end{tabular}

Sumber : Data Primer Setelah Diolah, 2017.

Keterangan :

Lingkungan Internal : Kekuatan > Kelemahan $(0,59)$

Lingkungan Eksternal: Peluang > Ancaman $(0,24)$

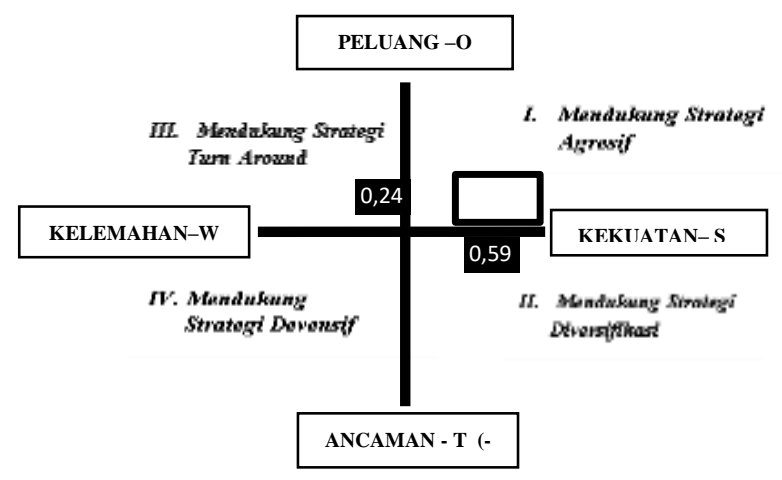

Gambar 1. Posisi Pengembangan Strategi Usaha Peternakan Babi
Gambar 1.menunjukkan posisi pengembangan strategi usaha peternakan babi berada pada kwadran I. Pada posisi ini sebuah usaha atau perusahaan memiliki posisi yang kuat dan peluang. Agar usaha ini dapat lebih berkembang diperlukan strategi dalam mengetahui setiap fakto-faktor lingkungan internal dan eksternal yang mempengaruhi perusahaan, khususnya memanfaatkan faktor kekuatan dan peluang untuk meminimalkan faktor kelemahan dan acaman.

\section{Pengembangan Strategi}

Hasil penelitian pada usaha peternakan babi yang telah diolah melalui hasil perhitungan faktor internal dan faktor eksternal, maka dapat digunakan pendekatan matriks SWOT. Dari hasil kwadran SWOT di atas, maka penerapan strategi yang dapat digunakan pada peternakan babi ialah strategi SO. Strategi SO merupakan strategi yang dapat digunakan usaha karena memiliki peluang dan kekuatan yang bisa dimanfaatkan dalam mengembangkan usahanya kemasa yang akan datang. Sehingga strategi ini dapat dikategorikan sebagai strategi yang menggunakan kekuatan internal industri untuk memanfaatkan peluang eksternal, melalui matriks SWOT IFAS dan EFAS menyatakan beberapa strategi alternatif untuk mendukung pengembangan usaha peternakan babi di Distrik Hubikiak Kabupaten Jayawijaya yang dapat digunakan sebagai strategi alternatif adalah :

1. Memiliki budaya yang kuat dan berkaitan erat dengan ternak babi, tentunya peluang dalam pemanfaatan pasar yang cukup tersedia dengan harga babi yang mahal.

Strategi ini dapat digunakan oleh pelaku usaha peternakan babi, dimana budaya yang kuat dan turun temurun hingga saat ini melakukan ternak babi, tentunya diharapkan terus mengembangkan usahanya, melalui manajemen perencanaan, peningkatan kapasitas sumber daya manusia dalam memaksimalkan modal yang tersedia. Harga babi yang cukup tinggi tentunya memberikan kekuatan dalam mendukung 
pengembangan usaha peternakan babi kemasa yang akan datang.

2. Ketersediaan pakan lokal seperti tanaman ubi jalar/hipere untuk mendukung usaha ternak babi, dan penggunaan bibit unggul, yang diharapakan adanya dukukungan dari pemerintah daerah lebih maksimal. Tentunya harapan bagi masyarakat lokal pada umumnya mengharapkan bantuan pemerintah, baik dalam bentuk dukungan peningkatan kapasitas sumber daya manusia, bantuan pakan tambahan, penyuntikan ternak dan bantuan lainnya.

\section{KESIMPULAN}

Berdasarkan hasil dan pembahasan dalam penelitian dapat disimpulkan sebagai berikut :

1. Hasil identifikasi faktor-faktor internal dan eksternal yang mempengaruhi pengembangan usaha peternakan babi di Distrik Hubikiak Kabupaten Jayawijaya ditemukan 8 faktor yang terdiri dari faktor kekuatan internal budaya, pakan lokal, harga dan bibit unggul, faktor kelemahan internal terdiri dari faktor modal, manajemen usaha peternakan, tingkat SDM, erkandangan, faktor peluang eksternal terdiri dari faktor pasar, dukungan dari pemerintah, jenis babi lain/babi non lokal, pesta budaya, sedangkan faktor ancaman eksternal terdidri dari faktor produk daging babi dari luar, penigkatan biaya, pencurian, dan penyakit.

2. Strategi pengembangan usaha peternakan babi dapat menggunakan strategi SO ialah, memiliki budaya yang kuat dan berkaitan erat dengan ternak babi, tentunya peluang dalam pemanfaatan pasar yang cukup tersedia dengan harga babi yang mahal. Ketersediaan pakan lokal untuk mendukung usaha ternak babi, dan penggunaan bibit unggul, yang diharapakan adanya dukukungan dari pemerintah daerah lebih maksimal seperti peningkatan kapasitas SDM, bantuan pakan tambahan, bibit unggul dan penyuntikan ternak.

\section{SARAN}

Bagi pelaku usaha peternakan babi agar dapat memaksimalkan usahanya melalui manajemen usaha yang lebih baik, penerapan sistem perkandangan, pemberian pakan tambahan dan penyutikan yang rutin.

\section{DAFTAR PUSTAKA}

Aritonang, D. 1993. Perencanaan dan Pengelolaan Usaha Ternak Babi. Jakarta: Penebar Swadaya.

Chamdi, A. N. 2005. "Karakteristik Sumber Daya Genetik Ternak Sapi Bali (BosBibos Banteng) dan Alternatif Pola Konservasinya" Jurnal Biodiversitas Volume 6 Nomor 1.

Chamdi, A.N. 2003. "Kajian Profil Sosial Ekonomi Usaha Babi di Kecamatan Kradenan Kabupaten Grobongan" Prosiding Seminar Nasional Teknologi Peternakan dan Veteriner, Bogor 29-30 September 2003. Bogor: Puslitbang Peternakan Departemen Pertanian.

Gobay, B. 2011. "Hubungan Antara Motif Ekonomi dan Motif Sosial terhadap Perkembangan Ternak Babi pada Masyarakat Suku Arfak di Manokwari” (Laporan Penelitian) Manokwari: Fakultas Peternakan Perikanan dan Ilmu Kelautan Universitas Negeri Papua.

Marani, O.Y. 2004. "Pemeliharaan Ternak Babi oleh Masyarakat Suku Arfak di Kampung Gaya Baru Kelurahan Wosi Distrik Manokwari” (Laporan Penelitian) Manokwari: Fakultas Peternakan Perikanan dan Ilmu Kelautan Universitas Negeri Papua.

Rangkuti, F. 2009. Analisis SWOT Teknik Membedah Kasus Bisnis. Reorientasi Konsep Perencanaan Strategis untuk Menghadapi Abad 21. Jakarta: Gramedia Pustaka Utama.

Rizky, Adelia. 2016. "Analisis Usaha Dan Strategi Pengembangan Ternak Kalkun Mitra Alam Di Desa Kabupaten Pringsewu" (Skripsi). Lampung: Fakultas Pertanian Universitas Lampung.

Soeharto, I. 1990. Manajemen Proyek Industri (Persiapan, Pelaksanaan, Pengelolaan). Jakarta: Erlangga.

Soewandi, Bayu Dewantoro Putro dan C Talib. 2015. "Pengembangan Ternak Babi Lokal di Indonesia" WARTAZOA Vol. 25 No. 1 Th. 2015 